\title{
Uji daya hambat rebusan daun pepaya (carica papaya) terhadap pertumbuhan Candida albicans pada plat resin akrilik polimerisasi panas
}

\author{
${ }^{1}$ Nurul A. Suni \\ ${ }^{2}$ Vonny N. S. Wowor \\ ${ }^{2}$ Michael A. Leman
}

\author{
${ }^{1}$ Kandidat Skripsi Program Studi Pendidikan Dokter Gigi \\ ${ }^{2}$ Program Studi Pendidikan Dokter Gigi Fakultas Kedokteran \\ Universitas Sam Ratulangi Manado \\ Email: anilannisa05@yahoo.co.id
}

\begin{abstract}
Unclean acrylic removable denture will be the gathering place of plaques that further become media for the growth of microorganisms, inter alia Candida albicans. Abnormal growth of fungi could result in denture stomatitis. Prevention can be done by using cleaning materials, however, these materials contain many chemical substances and are relatively expensive. Carica papaya is one of the herbs that contain active compounds which are antifungal. This study was aimed to determine the inhibition effect of papaya leaves on the growth of $C$. albicans isolated from the hot plate acrylic resin polymerization. This was a pure experimental study with a post test only control group design. Absorbance values were obtained by using a standard spectrophotometer with Mc Farland No. 1. The absorbance values were incorporated into Stainer formula to determine the total number of colonies of $C$. albicans. The results of the converted absorbance values were as follows: the papaya leaf $0.51 \times 10^{8} \mathrm{CFU}$; the positive control (polident) $2.5 \times 10^{8} \mathrm{CFU}$; and the negative control (sterile distilled water) $3.6 \times 10^{8} \mathrm{CFU}$. Conclusion: Papaya leaves (Carica papaya) had inhibitory effect on the growth of Candida albicans.
\end{abstract}

Keywords: papaya leaf (Carica papaya), removable denture acrylic plate, Candida albicans

\begin{abstract}
Abstrak: Kebersihan gigi tiruan lepasan akrilik yang kurang diperhatikan akan menjadi tempat berkumpulnya plak yang dapat menjadi media untuk bertumbuhnya mikroorganisme, antara lain Candida albicans. Pertumbuhan jamur yang abnormal dapat mengakibatkan denture stomatitis. Pencegahan dapat dilakukan dengan menggunakan bahan pembersih, namun pembersih yang beredar saat ini banyak mengandung bahan kimia dan harga yang relatif mahal. Daun pepaya (Carica papaya) merupakan salah satu tanaman herbal yang mengandung senyawa aktif yang bersifat antifungi. Penelitian ini bertujuan untuk mengetahui daya hambat rebusan daun pepaya terhadap pertumbuhan $C$. albicans yang diisolasi dari plat resin akrilik polimerisasi panas. Jenis penelitian ialah eksperimental murni dengan post test only control group design. Nilai absorbansi diperoleh dengan menggunakan spektrofotometer standar Mc Farland no 1, kemudian nilai absorbansi dimasukan ke dalam rumus Stainer untuk mengetahui jumlah total koloni $C$. albicans. Hasil penelitian menunjukkan nilai absorbansi setelah dikonversikan ke dalam rumus ialah pada rebusan daun pepaya 0,51 × $10^{8} \mathrm{CFU}$; kontrol positif (polident) 2,5 × $10^{8} \mathrm{CFU}$; dn kontrol negatif (akuades steril) 3,6 x $10^{8} \mathrm{CFU}$. Simpulan: Air rebusan daun pepaya (Carica papaya) memiliki daya hambat terhadap pertumbuhan Candida albicans.
\end{abstract}

Kata kunci: daun pepaya (carica papaya), plat gigi tiruan 
Proses menua pada manusia merupakan proses yang bersifat fisiologis dan normal terjadi. Proses menua dapat berdampak pada kemunduran fisik, psikologis maupun sosial, sehingga dapat menimbulkan masalah baik pada lansia itu sendiri maupun orang di sekitarnya. Seiring bertambahnya usia, semakin besar kerentanan seseorang terhadap kehilangan gigi, dan keadaan ini akan berdampak pada peningkatan penggunaan gigi tiruan. ${ }^{1}$

Berdasarkan data Riskesdas tahun 2013, proporsi penduduk Indonesia di atas 12 tahun yang menderita kehilangan gigi (edentulous) sebesar $1,7 \%$ dan yang menggunakan protesa (gigi tiruan) sebesar $1,5 \%$. Angka ini meningkat pada tingkatan usia di atas 65 tahun, yaitu proposi penduduk yang menderita kehilangan gigi (edentulous) sebesar $17,1 \%$ dan yang menggunakan gigi tiruan sebesar 5,8\%. Data tersebut menunjukkan bahwa jumlah pengguna gigi tiruan di Indonesia cukup besar. ${ }^{2}$

Gigi tiruan akrilik merupakan piranti untuk menggantikan permukaan pengunyahan dan struktur yang menyertai dari suatu lengkung gigi dan rahang. Pemilihan bahan resin akrilik disebabkan oleh sifatnya yang menguntungkan secara estetik dan dari segi ekonomi cukup terjangkau. Selain memiliki keunggulan, resin akrilik juga mempunyai kekurangan, yaitu mempunyai sifat porus yang merupakan tempat ideal untuk pengendapan sisa makanan sehingga menjadi tempat perkembangbiakan mikroorganisme. ${ }^{3}$

Terdapat dua macam gigi tiruan, yaitu gigi tiruan cekat dan gigi tiruan lepasan. Bahan pembuat basis gigi tiruan bermacammacam, antara lain dari bahan akrilik dan metal. Bahan basis yang hingga saat ini yang banyak dipakai, yaitu bahan resin akrilik. $^{4}$

Mikroorganisme yang sering dijumpai berkaitan dengan penggunaan gigi tiruan, yaitu jamur Candida albicans. Pemakaian gigi tiruan yang terus menerus dapat menghalangi proses pembersihan permukaan mukosa mulut. Kebersihan yang kurang diperhatikan akan mengakibatkan penumpukan plak dan sisa makanan, sehingga dapat meningkatkan jumlah koloni Candida albicans dan menjadi penyebab denture stomatitis. ${ }^{5}$

Denture stomatitis adalah suatu inflamasi pada mukosa mulut, bentuk utamanya atropik dengan lesi eritematosa dan hiperplastik. Inflamasi ini mengakibatkan perubahan lingkungan mikroorganisme rongga mulut dan menyebabkan infeksi pada mukosa. Sekitar $65 \%$ penderita denture stomatitis terjadi pada pengguna gigi tiruan. ${ }^{6}$ Terjadinya denture stomatitis dapat dicegah dengan pemeliharaan kebersihan gigi tiruan yang digunakan, sehingga tidak memberikan kesempatan pada jamur Candida albicans untuk berkembang biak.

Saat ini pengguna gigi tiruan menjaga kebersihan gigi tiruan dengan menyikat gigi tiruan secara rutin dan merendam pada larutan pembersih. ${ }^{7}$ Terdapat banyak jenis larutan pembersih yang dipakai selama ini dan kebanyakan menggunakan bahan dasar dari kimia dengan harga yang relatif mahal. ${ }^{8}$

Saat ini, penggunaan bahan herbal banyak dikembangkan sebagai bahan pembersih gigi tiruan. Daun pepaya (Carica papaya) merupakan salah satu tanaman yang daunnya mengandung flavanoid yang bersifat antifungi. ${ }^{9}$ Penelitian yang dilakukan Hidayah et al. ${ }^{10}$ menyatakan bahwa ekstrak daun pepaya (Carica papaya) memiliki efektivitas sebagai antifungi terhadap pertumbuhan Candida albicans. Penelitian mengenai air rebusan daun papaya sebagai antifungi terhadap Candida albicans belum pernah dilakukan. Penelitian ini bertujuan untuk mendapatkan daya hambat rebusan daun pepaya (Carica papaya) terhadap pertumbuhan Candida albicans pada resin akrilik polimerisasi panas".

\section{BAHAN DAN METODE PENELITIAN}

Penelitian ini dilaksanakan di Laboratorium Farmasi Fakultas MIPA dan Laboratorium Mikrobiologi Fakultas Kedokteran Universitas Sam Ratulangi pada bulan September-Oktober 2016. 
Sampel penelitian ini ialah jamur Candida albicans yang diisolasi dari plat gigi tiruan lepasan akrilik yang masih aktif digunakan oleh pasien yang memiliki gejala-gejala denture stomatitis pada mukosa mulut dibawah gigi tiruan.

Variabel penelitian yaitu rebusan daun pepaya (Carica papaya) $60 \%$ dan pertumbuhan Candida albicans pada plat akrilik polimerisasi panas. Pertumbuhan Candida albicans pada plat resin akrilik polimerisasi panas dilihat setelah perendaman pada masing-masing kelompok selama 6 jam (sesuai dengan jumlah waktu rata-rata pengguna gigi tiruan merendam gigi tiruan pada malam hari saat beristirahat). Setelah perendaman, dilakukan vibrasi menggunakan vortex selama 30 detik, kemudian dilakukan penghitungan menggunakan spektrofotometer dengan standard Mc Farland no 1 dengan panjang gelombang $560 \mathrm{~nm}$. Kemudian nilai absorbansi tersebut dilakukan penghitungan jumlah koloni dengan menggunakan rumus jumlah total koloni (rumus Stainer).

\section{HASIL PENELITIAN}

Pada penelitian yang dilaksanakan di Laboratorium Mikrobiologi Farmasi FMIPA Universitas Sam Ratulangi dengan menggunakan rebusan daun pepaya (Carica papaya) $60 \%$ dan larutan polident serta akuades steril sebagai bahan perendam lempeng akrilik polomerisasi panas yang telah terkontaminasi dengan Candida albicans dan dilakukan perendaman pada masing-masing bahan perendam selama 6 jam, diperoleh nilai absorbansi masingmasing larutan. Nilai absorbansi merupakan hasil penghamburan cahaya dari suatu biakan mikroba, sehingga dapat diketahui konsentrasi mikroba dalam media tersebut. Rerata nilai absorbansi masing-masing larutan dikonversikan dengan menggunakan rumus Stainer (Tabel 1).

Tabel 2 memperlihatkan rerata nilai dengan menggunakan rumus Stainer pada setiap larutan yang menunjukkan kelompok I rebusan pepaya sebesar $0,51 \times 10^{8} \mathrm{CFU}$; kelompok II larutan polident (kontrol positif) $2,5 \times 10^{8} \mathrm{CFU}$; dan kelompok III pada akuades steril (kontrol negatif) 3,6 x $10^{8}$. Perendaman resin akrilik polimerisasi panas dalam rebusan daun pepaya memiliki nilai absorbansi terkecil, sedangkan nilai absorbansi terbesar terdapat pada hasil perendaman menggunakan akuades steril.

Tabel 1. Rerata nilai absorbansi pada masingmasing kelompok setelah dilakukan perendaman selama 6 jam

\begin{tabular}{cccc}
\hline Sampel & \multicolumn{3}{c}{ Nilai absorbansi } \\
\cline { 2 - 4 } & $\begin{array}{c}\text { Rebusan } \\
\text { daun pepaya } \\
60 \%\end{array}$ & $\begin{array}{c}\text { Kontrol } \\
(+)\end{array}$ & $\begin{array}{c}\text { Kontrol } \\
(-)\end{array}$ \\
\hline 1 & 0,063 & 0,112 & 0,242 \\
2 & 0,077 & 0,134 & 0,200 \\
3 & 0,055 & 0,190 & 0,202 \\
4 & 0,069 & 0,134 & 0,267 \\
5 & 0,049 & 0,151 & 0,243 \\
6 & 0,047 & 0,196 & 0,163 \\
7 & 0,058 & 0,171 & 0,187 \\
8 & 0,045 & 0,171 & 0,196 \\
Rerata & 0,057 & 0,157 & 0,212 \\
\hline
\end{tabular}

Tabel 2. Rerata nilai absorbansi yang telah dikonversikan ke dalam rumus Stainer untuk mengetahui jumlah total koloni Candida albicans

\begin{tabular}{cccc}
\hline Sampel & \multicolumn{3}{c}{$\begin{array}{c}\text { Jumlah } \boldsymbol{C} \text {. Albicans pada media } \\
\left(\mathbf{x 1 0}^{\mathbf{8}} \mathbf{C F U}\right)\end{array}$} \\
\cline { 2 - 4 } & $\begin{array}{c}\text { Rebusan } \\
\text { daun pepaya } \\
60 \%\end{array}$ & $\begin{array}{c}\text { Kontrol } \\
(+)\end{array}$ & $\begin{array}{c}\text { Kontrol } \\
(-)\end{array}$ \\
& 0,66 & 1,64 & 4,24 \\
1 & 0,94 & 2,08 & 3,4 \\
2 & 0,5 & 3,2 & 3,44 \\
3 & 0,78 & 2,08 & 4,74 \\
4 & 0,38 & 2,42 & 4,26 \\
5 & 0,34 & 3,32 & 2,66 \\
6 & 0,56 & 2,82 & 3,14 \\
7 & 0,3 & 2,82 & 3,32 \\
8 & 0,51 & 2,5 & 3,6 \\
Rerata & \multicolumn{3}{c}{} \\
\hline
\end{tabular}

\section{BAHASAN}

Nilai absorbansi pada setiap kelompok dilakukan perhitungan menggunakan spektrofotometer. Hasil nilai absorbansi dimasukan ke dalam rumus Stainer untuk mengetahui jumlah koloni Candida albicans. Rumus Stainer merupakan rumus ketetapan untuk mengetahui jumlah koloni 
jamur yang didapatkan dari nilai absorbansi. ${ }^{13}$

Hasil rerata nilai absorbansi yang telah dikonversikan ke dalam rumus (Tabel 1) menunjukkan perbadaan antara masingmasing perlakuan. Jumlah ini diasumsikan sebagai Candida albicans yang masih bertahan hidup setelah dilakukan perendaman pada masing-masing media perendaman. Semakin besar nilainya, berarti semakin banyak jumlah jamur yang masih mampu bertahan ketika direndam dalam bahan pembersih tersebut. Hal ini juga dibandingkan dengan nilai absorbansi media tanpa kuman yang telah menjadi nilai ketetapan yaitu 0,03 sesuai dengan rumus Stainer dimana nilai yang mendekati nilai ketetapan dikatakan memiliki daya hambatan. ${ }^{13}$

Nilai rerata yang didapatkan setelah nilai absorbansi dikonversikan ke dalam rumus ialah: kelompok I sebesar 0,51 x $10^{8}$ CFU; kelompok II sebesar 2,5 x $10^{8} \mathrm{CFU}$; dan kelompok III sebesar 3,6 x $10^{8}$ CFU. Nilai tersebut memiliki perbedaan yang cukup besar, atau dapat dikatakan memiliki perbedaan bermakna.

Kelompok I yaitu rebusan daun pepaya memiliki efektifitas yang lebih baik dibandingkan dengan kelompok II polident dan kelompok III akudes steril. Hal ini disebabkan dalam penelitian ini rebusan daun pepaya yang digunakan ialah rebusan daun pepaya $60 \%$. Konsentrasi tersebut menentukan efektifitas ini. Semakin tinggi konsentrasi, maka semakin tinggi pula kandungan bahan aktif yang ada di dalamnya. $^{14}$

Kandungan dalam daun pepaya yang memiliki senyawa antifungi ialah flavonoid, yaitu suatu kelompok senyawa fenol yang terbesar yang ditemukan di alam. Senyawa ini merupakan zat dengan ciri warna merah, ungu, biru dan sebagian senyawa berwarna kuning yang sering ditemukan di dalam tumbuh-tumbuhan. Flavonoid dapat berikatan dengan dinding sel melalui sebuah kompleks protein-fenol, yang melibatkan adanya ikatan hidrogen antara protein dan fenol. Kompleks ini nantinya dapat menyebabkan kerusakan (denaturasi) ikatan hidrogen dalam protein pada dinding sel yang selanjutnya membuat matriks intrasel fungi keluar yang berakibat kematian sel itu sendiri. ${ }^{10,11,14}$

Polident merupakan sodium bikarbonat yaitu bahan kimia berbentuk kristal putih yang larut dalam air, bahan ini banyak digunakan dalam industri pembuatan pasta gigi dan pembersih gigitiruan. Sodium bikarbonat merupakan agen effervescent yang menghasilkan pembersihan kimia pada gigi tiruan dan senyawa asam sitrat yaitu bahan pengawet yang baik dan alami. Zat ini juga dapat digunakan sebagai zat pembersih dan anti oksidan. Asam sitrat pada tablet pembersih gigi tiruan memberikan aksi pembersihan kimia pada gigitiruan yang dapat menghilangkan deposit. ${ }^{15}$

Pemakaian bahan pembersih gigitiruan ini juga terdapat kekurangan yaitu aksi mekanik lebih kecil karena pembersihan dilakukan secara kimia; oleh karena itu dianjurkan untuk disikat. Dalam penelitian ini hanya dilakukan perendaman tanpa dilakukan proses penyikatan; hal ini yang menyebabkan kandungan rebusan daun pepaya lebih tinggi daya hambatnya jika dibandingakan dengan pembersih gigi tiruan effervescent. ${ }^{12,15}$

Akuades (aqua purificata, air murni) ialah air yang dimurnikan dari destilasi. Akuades tidak memiliki warna, berbau dan cairan yang jernih, selain itu juga memiliki berat molekul sebesar 18,0 g/mol dan $\mathrm{PH}$ antara 5-7. ${ }^{15}$ Akuades steril tidak memiliki sifat fungisidal ataupun fungistatik. Hal ini disebabkan tidak adanya kandungan aktif dalam akuades steril. Akuades memiliki kandungan beberapa jenis ion yang justru baik untuk pertumbuhan mikroba. ${ }^{16}$

\section{SIMPULAN}

Dari hasil penelitian dan bahasan dapat disimpulkan bahwa air rebusan daun pepaya memiliki daya hambat terhadap Candida albicans.

\section{SARAN}

1. Disarankan untuk dilakukan penelitian lebih lanjut mengenai daya hambat daun pepaya terhadap pertumbuhan 
Candida albicans yang diisolasi pada plat gigi tiruan lepasan akrilik dengan berbagai konsentrasi sehingga dapat diketahui kadar hambat minimal.

2. Disarankan dapat dilakukan penelitian lebih lanjut mengenai kemampuan air rebusan daun pepaya untuk dijadikan bahan alternatif pembersih gigi tiruan guna mencegah pertumbuhan Candida albicans.

\section{DAFTAR PUSTAKA}

1. Ratmini NK. Arifin. Hubungan kesehatan mulut dengan kualitas hidup lansia. Jurnal Ilmu Gizi. 2011;2(2):139-47.

2. Badan Penelitian dan Pengembangan Kesehatan Departemen Kesehatan RI Riset kesehatan dasar (RISKESDAS) 2013. Jakarta, 2013; p. 189.

3. Wahyuningtias E. Pengaruh ekstrak Graptophyllum pictum terhadap pertumbuhan Candida albicans pada plat gigi tiruan resin akrilik. Indonesia Journal of Dentistry. 2008;15(3):18791.

4. Dama C, Soelioangan S, Tumewu E. Pengaruh perendaman plat resin akrilik dalam ekstrak daun kayu manis (Cinnamomum Burmanii) terhadap jumlah blastopora Candida albicans. eG. 2013;1(1).

5. Paskalis S, Irmagita A. Candidal leukoplakia on patient with removable denture. Journal of Dentistry Indonesia. 2012;19(2):47-50.

6. Hardianty AR. Hubungan lamanya pemakaian gigi tiruan penuh terhadap terjadinya denture stomatitis pada penderita di RSGMP drg. Hj. Halimah Dg. Sikati FKG Unhas Kadea [Skripsi]. Makassar: Universitas Hasanuddin; 2012.

7. Pristianinggum N, Soebagio, Munadziroh
E. Uji stabilitas mikrobiologis pembersih gigi tiruan dengan minyak atsiri kulit batang kayu manis (Cinnamomun Burmannii). Jurnal PDGI. 2013;62(3):89-94.

8. Hadjieva H, Dimova M, Todarov S. Stomatitis prosthetica - a polyetiologic disorder. IMAB. 2006; 12(2):38-41.

9. Rehena JF. Uji aktivitas ekstrak daun papaya (Carica Papaya. Linn.) sebagai antimalaria in vitro. Jurnal Ilmu Dasar. 2010;11(1):96-100.

10. Rahmawati I, Noviana S, Rinanto $Y$. Uji aktivitas antifungi fraksi n-heksan, etil asetat dan air dari daun papaya (Carica Papaya Linn.) terhadap Candida albicans ATCC 10231. Jurnal Farmasi Indonesia. 2010;7(1): 30-4.

11. Materia Medika Indonesia, Jilid V, Jakarta: Departmen Kesehatan RI, 1989; p. 116-20.

12. Priyono. Enzin papain dari pepaya (Carica papaya). [cited 2013 Nov 20]. Available from: http://priyonoscience. com/2009/07enzim-papainpepaya. html.

13. Cushnie TP, Lamb AJ. Antimicrobial activity of flavonoids. Int $\mathbf{J}$ Antimicrob Agent. 2005;26:343-5.

14. Subrata G. Antifungal properties of sodium peroxide and sodium hypochlorite as a denture cleanser for full acrylic denture in vitro. Bandung: Dept of Prosthodontics Faculty of Dentistry Universitas Padjadjaran; 2010.

15. Suleiman MN. Antifungal properties of leaf extract of neem and tobacco on three fungal pathogens of tomato (Lycopersicon isculentum Mill). Pelagia Res Library. 2011;2(4):21720.

16. Sarjoni B. Kamus Kimia (2nd ed). Jakarta: Rineka Cipta, 2003. 